\title{
A critical review of World Council of Churches' responses to the global challenges of migration
}

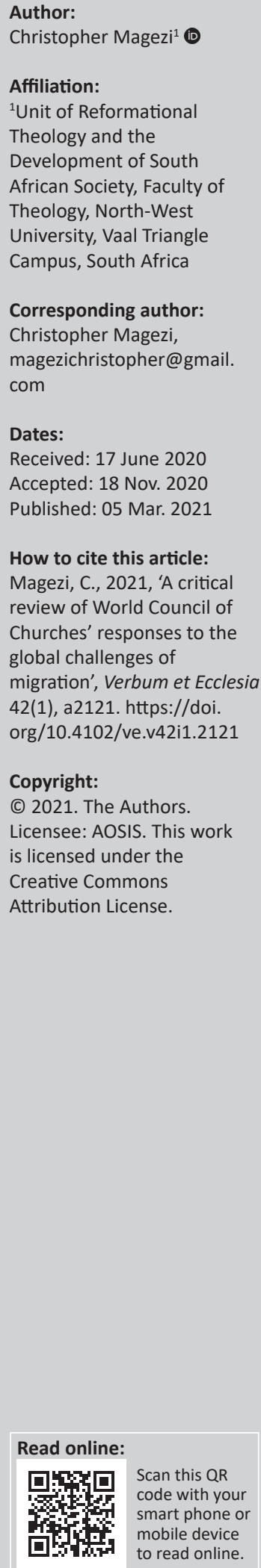

This article views migration as a topical issue that poses challenges, especially in recent times, for migrant sending and hosting nations and the migrants themselves. In response, the church has recommended various ways of addressing the prevailing migration situation. In acknowledging these proposed intervention measures, this article aims to establish if the churches' approaches to the migration situation are harmonised and integrated. To accomplish this, the article reviews the World Council of Churches' (WCC) responses to migration challenges as a window and insight into the broader approaches employed by the churches. The WCC mirrors the churches' efforts, strategies and positions on migration issues. However, some churches do not adequately execute some of the interventions because of lack of finances to meet the material needs of the migrants, whilst others break the laws of the land as they respond to migration challenges. The article concludes by making recommendations on how the WCC can improve some of its intervention strategies in order to effectively respond to migration challenges.

Intradisciplinary and/or interdisciplinary implications: This article views migration as a topical issue that poses challenges to migrant sending and hosting nations and the migrants themselves. It acknowledges that the Church has recommended various ways of addressing the prevailing situation of migration. After acknowledging the aforesaid, it then proceeds to determine if the Churches' approaches and interventions to the migration situation are harmonised and integrated. As such, the article is interdisciplinary as it seeks to understand the integration and harmonisation of the churches' approaches and interventions to the topical issue of migration.

Keywords: World Council of Churches; migration situation; migration challenges; migrants' challenges; church responses and interventions; strengths and weaknesses of WCC interventions to migration challenges; formation and focus of World Council of Churches.

\section{Introduction}

Migration has been a topical issue in recent times (Castles \& Wise 2008; World Migration Report 2020). A considerable number of scholars (i.e. Bose 2014:23; Corhen \& Sirkeci 2011:1; Chelius 2014:32-33; Gilmore 2016; Rajendra 2014:305; Ridsdel 2014:27-28; Thomsen 2016:17) have documented various challenges associated with migration. Various churches' responses can be recommended as solutions to the situation (Magezi 2017:1-9). The article intends to establish if the various churches' approaches are harmonised and integrated. One way of understanding what the churches are doing is to review the World Council of Churches' (WCC) response to the challenges of migration. Such a review provides insights into the broader approaches employed by the churches, as the WCC mirrors their efforts, strategies and positions on migration issues (cf. Cloud 2013:n.p.; Tulun 2020:1). Thus, the aim of the review is to analyse the WCC responses to the global challenges of migration, especially the strengths and weaknesses of its intervention approaches. The analysis will form the basis for recommendations to strengthen the responses of the churches' and the WCC itself as an institution.

\section{The formation and focus of the World Council of Churches}

Tulun (2020:1), Cloud (2013:n.p.) and Brunn (2001:69) define the WCC as a worldwide inter-church organisation that was constituted in 1948 at Amsterdam, Holland, the Netherlands and is headquartered in Geneva, Switzerland. At its inception, the WCC comprised at least 147 members, mostly Protestant European churches and North American organisations (Brunn 2001:69; Tulun 2020:1). Brunn (2001:69) observed that the WCC is not the first worldwide Christian inter-church organisation to be established. It is preceded by international 
organisations such as the Global Conference of Mission that was convened in Edinburgh in 1918, the International Conference of 1921 (which lasted until the 1950s) and the Lausanne Conference of 1927, which still exists (Brunn 2001:69). In addition, the other inter-church organisations that precede the WCC includes (Brunn 2001):

... the World Sunday School Association, which was reorganized in 1924 and named the World Council of Christian Education in 1946; it was integrated into the WCC in 1971. (pp. 69-70)

Brunn (2001:6970) noted that these early conferences were important in setting the agenda for subsequent WCC's efforts. Tulun (2020:1) concurs with Brunn's (2001) aforesaid conception view and further advances that the WCC is the most extensive and inclusive ecumenical movement [organisation]in the world, a movement that calls for Christian unity'. Cloud (2013:n.p.) perceives the WCC as an 'international ecumenical union of roughly 340 denominations in 120 countries representing more than 500 million professing Christians'. Tulun (2020:1) states that the WCC'... now has 345 member churches representing an estimated 500 million Christians around the world'. Now, because of an increment in member churches from many continents, Tulun (2020:1) notes that the WCC now '... has many Orthodox, Anglican, United and other member churches from more than 110 different countries from all continents'. The foregoing submissions clearly show that the WCC is no longer a predominantly Protestant European and North American organisation. Instead, it is now a worldwide inter-church organisation with membership from churches of different denominations from all the continents.

The all-inclusiveness of the WCC might be challenged by the fact that the Roman Catholic Church (RCC) and some rapidly growing Independent and Pentecostal churches are not its members (Brunn 2001:70; Cloud 2013:n.p.; Raiser 1997:92-93; Tulun 2020:1). It should be noted that the RCC and some of these Independent and Pentecostal churches were not denied membership by the WCC, as the decision to join the council entirely lies with the churches and denominations themselves (Tulun 2020:1). However, although all churches and denominations are free to join the WCC, it is worth noting that all prospective members should concur on the council's commonly acknowledged founding theological tenet, namely the recognition of Jesus' life, teachings and adherence to Christian faith (Tulun 2020:1). Tulun (2020:1-2) affirmed that the RCC is not a member of the WCC; however, it has been working closely with the WCC, that is, it sends observers to all major WCC conferences, as well as to its central meetings and assemblies.

The WCC mission comprises calling for global unity and solidarity amongst Christians in fighting racism and dealing with humanitarian and refugee issues, amongst others (Brunn 2001:70). At its founding in Amsterdam (Holland) in 1948, the WCC embarked on a journey to deal with many rampant issues at that time such as racism, political and refugee issues in Europe. ${ }^{1}$ That is to say, in the aftermath of the devastation wreaked by the First World War, human rights ${ }^{2}$ and spiritual concerns were given due consideration in the WCC's founding mission (Brunn 2001). Thus, Van Eideren (1990:39) and Brunn (2001:70) posit that the WCC prioritises the cooperation of churches in fighting against all forms of evil against human dignity and well-being. Such evils include threats to social justice and the environment. In other words, the aforementioned concerns within the WCC '[take] precedence over concern for traditional church divisions' (Brunn 2001:70). In this light, I contend, together with Tulun (2020:1, cf. Oxley 20103), that:

[The] WCC is the most extensive and inclusive ecumenical movement [organisation] in the world; a movement that calls for Christian unity. Christian unity, according to the WCC, should not be understood as the creation of a world church above all other churches. For the WCC, Christian unity is about cooperation and solidarity amongst Christians in issues relevant to Christians around the world. (p. 7)

In the foreword to the WCC's 10th Assembly, Bussan 2013, Olav Fykse Tveit, the General Secretary of the WCC (2013a) substantiates that:

An assembly of the World Council of Churches occasions not only fellowship and celebration, prayer and worship. It also calls for serious religious reflection on the needs of the world, the role of ecumenical Christianity, and the recent achievements and future aims of ecumenical Christian engagement. (p. vii)

Now, in view of the WCC's response to migration challenges, Kantyka and Kul (2015:124-125) note that the question of refugees, migrants, asylum-seekers, and internally displaced and uprooted people had always been on the WCC's agenda. The WCC's first major attempt to analyse the subject of migration is contained in its Central Committee's document of 1995, namely: A Moment to Choose: Risking to Be with Uprooted People. The issues that the WCC grapples within the aforementioned document 'are as relevant today as they were at that time' (WCC 2013a:4). That is, even 25 years later, the WCC Central Committee's document has not lost essence on migration issues.

In 2015, the WCC published its second document on migration, namely The 'other' is my neighbour: Developing an ecumenical response to migration. This document reflects the joint perspective of migrant churches and established historic congregations (WCC 2015a:2). It is a product of 2 years of work, as the WCC (2015a:1) stated that in 2011 and 2012,

1.Brunn (2001:70) noted that, in its first decade, the wCC dealt with refugee issues that were rampant in Europe and Palestine. Notably, the work of WCC was not originally oriented to address global issues; however, with the end of colonialism in Africa and many parts of the world in the 1960s and 1970s and the emergence of the Third World Thinking, the focus of the WCC was redirected to global political issues.

2.Van der Bent (1986:4-5) and Brunn (2001:70) argued that the Commission on the Churches on International Affairs (CCIA) 'was active in drafting the UN Declaration of Human Rights in 1948, and especially the language included on religious libertie Human Rights in 1948, and especially the language included on religious liberties and freedom of conscience. It has maintained formal relations with the UN Economic and Social Council, FAO, UNESCO, UNHCR, ILO, WHO, UNRWA, UNICEF
and other committees'.

3.Oxley (2010:7) advanced that the World Council of Churches is 'the broadest and most inclusive amongst the many organized expressions of the modern ecumenical movement, a movement whose goal is Christian unity'. 
church representatives, church-related organisations and several migration networks met in various places under the coordination of WCC to consider the theme 'Who is my neighbour? Migration and the ecclesial landscape - an ecumenical response to migration'. This is why Kantyka and Kul (2015:125) contended that the second document constitutes the analyses of biblical and theological aspects of ecclesial implications and ecumenical responses to migration. From a theological perspective, the issues that provided structure and focus for the theological debate include (WCC 2015a):

\begin{abstract}
... the ways in which we view or understand ourselves and 'others'; the moral imperative of holding powers accountable for the present economic policies that thrive on the abuse of human beings and the creation; and practical steps to encourage and equip congregations to become just and inclusive communities. (pp. 1-2)
\end{abstract}

The WCC's second document on migration affirms three convictions that should drive Christian response to migrations and, consequently, migrants' challenges. Firstly, Christian conviction about the sacredness of all human life and the sanctity of creation is rooted in the concepts of God's benign creation and that humanity is created in the image of God (imago dei). The aforementioned results in the WCC's (2015a) firm belief that:

Respect for the human dignity and the worth of every person regardless of age, abilities, ethnicity, gender, class, nationality, race and religion is foundational to our faith. Our faith compels us to ensure that human life, physical security and personal safety are upheld in law and institutions. (p. 2)

Secondly, the biblical values of love, justice and peace compel Christians to renew their response to the marginalised and excluded, as stated in Matthew 22:37-39, in which God's commandments are summed up as: loving God with all your heart, mind and soul, and loving your neighbour as you love yourself (WCC 2015a:3). The foregoing theological conviction underlies the WCC's (2015a) understanding that:

The realm of God is a vision of a just and united world. The challenge of prophesy and of Jesus' teaching is to liberate and equip Christians to have the courage to work for alternative community, to work for peace and justice, which is to address the causes, which uproot people ... There is no peace without justice or full justice without peace (Amos 5:24). Our faith compels us to struggle for justice and peace for all; to work for a world where economic, political and social institutions serve people rather than the other way around. (p. 3)

The third conviction is the biblical challenge for the church to build an inclusive community that requires Christians to embrace the uprooted in service and witness (WCC 2015a). This implies that:

Christians are called to be with the oppressed, the [marginalised] and the excluded in their suffering, their struggles and their hopes. A ministry of accompaniment and advocacy with uprooted people upholds the principles of prophetic witness and service - diaconia. We cannot desert the 'needy', nor set boundaries to compassion (Hebrews 13:2, Luke 10:25-37, Jeremiah 5-7). (p. 3)
From the foregoing discussion, it emerges that the WCC is a worldwide representative organisation comprising many churches and denominations across the continents. The WCC views its member churches and denominations as faith communities that have a religious mandate to respond to global migration challenges (Jackson \& Passarelli 2016: 28). The WCC's conviction to respond to migration challenges arises from the Bible, which stipulates that Christians should respect human dignity as all people are bearers of the image of God (Jackson \& Passarelli 2016). In addition, Christians are called to love their neighbours, including migrants, by welcoming and protecting them from any form of injustice in their new homelands (Jackson \& Passarelli 2016). To understand if churches have harmonised and integrated approaches to migration, one can review the WCC's responses to migration challenges. These responses provide insights into the broader approaches employed by churches, as the WCC mirrors the efforts, strategies and position of the former on migration issues. The ensuing section discusses the WCC's responses to migration challenges.

\section{The World Council of Churches' responses to migration challenges Coordinating migration responses by various stakeholders}

The WCC coordinates various stakeholders' responses to migration challenges by bringing them into efficient and effective relationships. For instance, from 14 to 16 June 2016, the WCC convened the Ecumenical Conference in Lunteren, the Netherlands, to intensify efforts in welcoming and embracing migrants (WCC 2016a:1). The conference was attended by the Conference of European Churches (CEC), the Churches' Commission for Migrants in Europe (CCME) and the Protestant Church in the Netherlands (PKN) (WCC 2016a:1). This conference brought together more than 60 experts, volunteers and representatives of church and ecumenical organisations that work with and for refugees in local parishes and groups in various European countries (WCC 2016a).

The conference was convened to respond to growing fears amongst many church and Christian organisations. These concerns include: (1) fear of the violence that drives many refugees from their countries of origin, (2) fear of the dangers that refugees face when travelling to their desired destinations, as evidenced by the high number of refugees who drown in the Mediterranean sea and (3) the fear of the reception - or rejection of refugees in their desired countries of destinations (WCC 2016a). Upon arrival in countries of safety, refugees risk being rejected because citizens of the prospective hosting nations fear that the migrants, particularly refugees, might destabilise their societies and ways of life (WCC 2016a:2). These fears are usually perpetuated by nationalist political movements in a bid to stoke the fires of insecurity and xenophobia (WCC 2016a). Consequently, a refugee crisis escalates from being a simple humanitarian issue to a security issue (WCC 2016a). 
Against this background, the joint message of the Lunteren conference delegates was derived from Isaiah 41:10 that tells God's people to 'have no fear' because God is with them (WCC 2016a). The reason for this message is that: 'Fear paralyses where effective solidarity and compassion in the receiving countries is a vital, necessary condition in offering humanitarian responses to refugee needs' (WCC 2016a:1). According to the WCC (2016a:1), the representatives at Lunteren Ecumenical Conference voiced concerns against the anti-refuge trends that were visible in leading political parties. The conference expressed solidarity with governments that were experiencing anti-refugee pressures from their societies. Such pressures often dissuade governments from fulfilling their obligations to receive migrants, as stipulated under European and international human rights treaties (WCC 2016a). Also, the churches and civil organisations that were entangled in social tensions amongst their constituencies, which resulted in the former hesitating to continue assisting refugees with basic needs such as shelter, food, legal aid and counselling (WCC 2016a). The churches and related organisations were challenged to remain focused on their call to safeguard the dignity and wellbeing of refugees (WCC 2016a). Thus, based on the foregoing discussion, it is important to state that the (WCC 2016a):

[encourages] churches in Europe to engage with societies, to create spaces to meet refugees, talk with each other about each others' fear and foster active participation. It is also of vital importance that interfaith relations are encouraged in aid to tackle fear. Solidarity and communication should be demonstrated by faith communities together. (p. 3)

Furthermore, on 18 September 2018, the WCC coordinated a world conference on xenophobia, racism and populist nationalism in the context of global migration. The conference was attended by the UNHCR, Regional Representative Southern Europe, and the Pontifical Council for Promoting Christian Unity and Disaster for Promoting Integral Human Development. The delegates also discussed the challenges of migrants, particularly refugees and how the various stakeholders could respond to the challenges of migrants (WCC 2018a). This indicates that the WCC does not solely coordinate intra-church responses, but also interfaces with non-Church organisations such as the UNHCR to spearhead a global response to migration challenges.

\section{Integration of migrants in native churches}

Stromberg (2003:48) stated that the CCME is part of the World of Church Councils, which was founded in 1964 with the assistance of the WCC. In Mapping Migration and Mapping Churches Responses in Europe, Jackson and Passarelli (2016:2; cf. Adele 2012:408-414) argued that as part of the World of Church Councils, the CCME is an intra-church ecumenical organisation in Europe that (2016) :

[S]erves the churches in their commitment to promote the vision of an inclusive community through advocating for an adequate policy for migrants, refugees and minority groups at European and national level. (p. 2)
Its members include the Anglican, Orthodox and Protestant churches, Councils of Churches and church-related agencies in 18 European countries (Jackson \& Passarelli 2016; cf. Adele 2012:408-414).

The CEC cooperates with the WCC, the mother body that ushered it into existence (Jackson \& Passarelli 2016:2; Stromberg 2003:48). Most of the churches in Europe have embraced migrants and they understand that their presence challenges the churches' identities and future (Jackson \& Passarelli 2016; Stromberg 2003:48). Consequently, the churches have to consider a number of factors such as multicultural worship and the nature of migrants' participation in church, which entails encouraging some of them to take up leadership positions in order to reflect the diversity and unity of the church that the Bible speaks about (Jackson \& Passarelli 2016:95-99). To establish how the churches in Europe integrate migrants, Jackson and Passarelli's (2016:95ff) empirical research on 35 churches in 19 European countries ${ }^{4}$ can serve as an example. The research revealed that $60 \%$ of the surveyed churches have between $6 \%$ and $100 \%$ of migrants in their membership, whilst $48.5 \%$ churches have between $6 \%$ and $20 \%$ of migrants in their membership.

As international migrants come from different national, cultural and language backgrounds, Jackson and Passarelli (2016:98) avow that some churches in Europe have multicultural worship policies that recognise ethnoreligious groups. The ways in which multicultural worship policies are applied determine the migrants' tenures in a given church (Passarelli 2016). Most parishes where international migrants and nationals worship together fall into three categories, namely those with only a small number of migrants, those which are migrant-led and those that have policies for promoting multicultural worship (Jackson \& Passarelli 2016:98-99). For instance, the Federation of Churches in Austria has between 5\% and 20\% migrant worshippers, who usually worship separately at different times, although there are occasional combined services throughout the year (Jackson \& Passarelli 2016:103). The Federation employs one person who is in charge of intercultural issues at national level and it also has an international partnership with churches in Ghana (Jackson \& Passarelli 2016).

In Belgium, migrants from Congo, Rwanda and Pakistan constitute $5 \%-20 \%$ of the United Protestant Church's membership (Jackson \& Passarelli 2016). Here, members from various ethnic backgrounds can either worship together or at separate times. From $5 \%$ to $20 \%$ of leadership positions in this church are held by migrants (Jackson \& Passarelli 2016). The Church of Cyprus (Orthodox) has less than 5\% migrant membership. This church conducts both joint and separate Sunday services, in addition to one monthly joint worship

4. These countries are Ireland, Austria, Belgium, Cyprus, Czech Republic, Denmark, Finland, France, Germany, Hungary, Iceland, Ireland, Italy, the Netherlands, Norway, Portugal, Spain, Sweden, Switzerland and the United Kingdom. 
meeting (Jackson \& Passarelli 2016). The Czechoslovak Hussite Church has fewer than 5\% migrant membership, mainly from Czech, Polish, Roma and Korean ethnic minorities. The church conducts bilingual services in Czech and Polish (Jackson \& Passarelli 2016). The Evangelical Lutheran Church of Denmark (ELKD) has fewer than 5\% migrant members. In this church, Christians form their own congregations based on confession, language and ethnicity, thus, they are not entirely integrated into the ELKD (Jackson \& Passarelli 2016:104).

The Evangelical Lutheran Church of Finland (ELCF) also has fewer than 5\% migrant membership, mainly Swedish, Russian, German, Sudanese and Congolese. The ELCF communities are languages specific and ethnic-based worshippers (Jackson \& Passarelli 2016). From 5\% to 20\% of the Methodist congregation in the Republic of Ireland are migrants from Africa, India, the Philippines, other European countries and Brazil (Jackson \& Passarelli 2016:107). Its worship patterns include joint and separate worship times every Sunday, and a joint monthly service (Jackson \& Passarelli 2016). Jackson and Passarelli (2016:99) noted that whilst the surveyed member churches of the WCC in Europe are making effort to integrate migrants into all aspects of the church, including leadership, there is still much that can be done. Five per cent of their leadership positions in $42.8 \%$ of the surveyed churches are occupied by migrants. In $25.7 \%$ of these churches, $5 \%-20 \%$ of the leaders are migrants. Furthermore, whilst young people are vital for the present and future of the parishes and local congregations, it is apparent that only a few of the surveyed churches organise separate activities for them on the basis of ethnicity (Jackson \& Passarelli 2016:101).

In spite of the apparent lack of migrant integration practice and policy in European churches, in November 1999 and May 2006, the Mission and Evangelism Team of the WCC held meetings to look for ways to bring together people from churches in various countries, where multicultural ministry was a growing concern (Stromberg 2003:46). The participants of the first meeting formulated a theological draft that affirmed a Trinitarian basis of the community that emphasised diversity and unity. Yoo-Crowe and Crowe (2000) underscored the multicultural ministry of the member churches of the WCC, which is inherent in the Trinitarian doctrine of God in the following way:

In God's grace, the love which enables the unity of the different persons of the Trinity also enables us to live in the differences of our cultural and individual particularity .... The Holy Spirit brings Christ's reconciliation to the human community in such a way that we are not reduced to a single type but enhanced in the richness of our diversity. (pp. 12-13)

In this way, the WCC advances a multicultural community that upholds diversity and unity by calling its member churches to allow migrants to participate in church leadership and conduct worship in vernacular. Such integration is possible, as the kingdom of God calls for a community of diversity where people from all ethnic, linguistic and national backgrounds can worship together. Furthermore, the Trinitarian doctrine of God challenges the church to be responsive to social realities (Stromberg 2003:46; Yoo-Crowe \& Crowe 2000:13-14). Indeed, the Trinitarian theology of God reveals that the different persons of the Godhead live in unity, thus, portraying a social reality that the church should emulate, as it should be a model of multicultural community that acknowledges differences and unity amongst migrants and the native congregants of migrant hosting nations' churches (Stromberg 2003; Yoo-Crowe \& Crowe 2000).

Regrettably, the member churches of the WCC in Europe still have a long way to go in integrating migrants in accordance with the Trinitarian theology of God. Jackson and Passarelli (2016:16) stated that, amongst many other things, migrants choose their destination countries within the European Union (EU) on the basis of cultural and linguistic support offered by churches. Stated otherwise, migrants tend to go to countries and churches in which they are taught the language and culture of the hosting nations, which enables them to easily integrate in churches and societies at large (Jackson \& Passarelli 2016).

\section{Provision of material support to vulnerable migrants}

The WCC, the Vatican Office for Integral Human Development and the Pontifical Council for the Promotion of Christian Unity jointly organised a three-day conference (WCC 2018b). The conference challenged the member churches to help vulnerable migrants with material support such as food and clothes (WCC 2018b). The conference stressed that migration was 'a feature of the human condition and that Christians are called to welcome the stranger, standing up for the rights and dignity of all people' (WCC 2018b). In addition, the delegate churches indicated that they would provide legal and financial assistance for newly arrived migrants, and shelter for those who were homeless. The member churches also agreed to provide the migrants with food and clothes, as well as assist with work placement and school enrolment for adults and children, respectively (WCC 2018b).

In agreement with the aforesaid, Jackson and Passarelli (2016) highlighted the need for WCC member churches to offer material support to migrants. Many European churches such as the United Protestant Church in Belgium, the Church of Cyprus (Orthodox), the Czechoslovak Hussite Church, the ELKD, the ELCF and the Methodist Church in the Republic of Ireland offer migrants material support such as food parcels, given that many migrant families and individuals take time to settle down or get jobs in their host countries (Jackson \& Passarelli 2016).

In a meeting with business and political leaders that were gathered in advance of the World Economic Forum (WEF) in Switzerland in 2016, Reverend Doctor Olav Fykse Tveit, the general secretary of the WCC spelt out what came to be known as the ten commandments of food aid (Bread for the 
World 2016: n.p.). He called on the various organisations to view food through the lens of social justice in which all human beings, including the migrants, need food for their human dignity (Bread for the World 2016). In other words, 'food is sacred, as it is a gift from God to sustain our lives through sharing' with those that do not have, such as vulnerable migrants, particularly refugees (Bread for the World 2016). Reverend Doctor Tveit challenged the WEF delegates to work together to address the challenge of climate change and other barriers that threaten food security across the continent, so that food would always be available for all people (Bread for the World 2016). Indeed, this indicates how the WCC prioritises the importance of material support, such as food provision, to vulnerable migrants.

\section{Advocating for the human rights of migrants}

Jackson and Passarelli (2016:101-107) stated that many WCC and CCME aligned churches in Europe are involved in advocacy for the asylum and human rights of migrants. The Federation of Churches in Australia, the United Protestant Church in Belgium, the Czechoslovak Hussite Church, the ELKD, the ELCF, the Evangelical Church in Germany, the Church of Greece (Orthodox), the Lutheran Church of Iceland and the Methodist Church (Republic of Ireland) advocate for the rights of migrants in cooperation with other churches and church councils (Jackson \& Passarelli 2016). For instance, the Presbyterian Church in Ireland does its advocacy work in conjunction with the Irish Council of Churches, the World Communities of Reformed Churches, the Irish Inter-Church Meeting and the CEC (Jackson \& Passarelli 2016:108), whilst the Church of Greece (Orthodox) works with the Integration Centre for Working Migrants, commonly known as the KSPM-ERP (Jackson \& Passarelli 2016:106-107).

The Integration Centre for Working Migrants is a non-governmental organisation (NGO) for the churches in Greece, which works with other European and international entities that defend the human rights of migrants, particularly refugees (Jackson \& Passarelli 2016:106). This role aligns with the WCC's 10th Assembly held in 2013, which called on its ecumenical churches to fight for justice and peace for migrants, especially refugees (WCC 2013b:n.p.). The 10th Assembly charged its member and affiliate organisations to defend vulnerable people's rights to education, health care, property ownership, travel and access birth and death certificates. This call arises from the WCC's (2013b) conception that:

Without protection from any state due to their lack of legal identity, stateless people are vulnerable to discrimination, exploitation, violence. Women and children are particularly vulnerable to exploitation. (n.p.)

The WCC's advocacy for the rights of vulnerable migrants was mainly triggered by the influx of Syrian refugees into Europe in 2015, which European Union nations failed to humanely deal with (Press Release No. 15/35). In response to the aforementioned, on 10 September 2015, the WCC, the CEC and the CCME released a joint letter calling on all their member churches to double their efforts in receiving, supporting and protecting refugees in their respective regions (Press Release No. 15/35). In conjunction with the aforesaid intra-church organisations, the WCC advocates for a Common European Asylum System that includes decent reception conditions for refugees and a common European Resettlement scheme that puts human dignity at the centre of the process (WCC 2013b). This entails lobbying the European governments to take care of the refugees, who usually do not have access to healthcare and education upon arrival (WCC 2013b).

The WCC consistently urges its member churches to advocate for the rights of migrants. At its 10th Conference, the council collaborated with the Bread of the World to organise a future conference, which was later held in Germany between 5 and 6 September in 2017 (WCC 2017a). This conference focused on addressing the needs of vulnerable refugees, considered as stateless in the European context (WCC 2017a). The conference was attended by 25 representatives from faith-based and church organisations, civil society and the UNHCR. The Germany conference was one of the many regional-focused conventions held by the WCC, where relevant stakeholders positively responded to migration challenges (WCC 2017a). In a nutshell, the conference tried to influence European people and governments to adopt humane approaches towards refugee protection, in line with the relevant European and international conventions. These approaches include legal and secure access to Europe for those in need of protection (Press Release No. 15/35).

Furthermore, when American President, Donald Trump, issued an executive order that banned migration ostensibly to prevent foreign terrorist entry, the WCC, the ACT Alliance and the Lutheran World Federation released a joint statement against Trump's executive order (WCC 2017b). The statement affirmed solidarity with American Christian leaders who opposed Trump's position (WCC 2017b). The joint statement insisted that Christians have a call to love and welcome migrants, particularly internally or externally displaced refugees (WCC 2017b). The statement further stressed on the biblical notion that Christ's followers are sanctioned to treat migrants as they would want to be treated themselves (cf. Lv 19:33-34; Dt 23:15-16; Mt 25:34-36) (WCC 2017b). Finally, the joint statement challenged the United States of America to offer refuge and protection to all those in need because these rights are enshrined under international institutions and laws of migration (WCC 2017b).

Furthermore, the Africa Press Office (APO) states that following the 2019 xenophobic incidents in South Africa, the WCC sent 16 delegates, consisting of people from all over the world, to meet with President Cyril Ramaphosa and his cabinet between 07 and 09 December in 2019 (APO 2019:n.p.). The visit was (APO 2019):

[I]ntended to be a journey of solidarity and spirituality, which [sought] a mutual transformation between people - both those who have visited and those who have been visited - walking together on a Pilgrimage of Justice and Peace. (n.p.) 
The delegates wanted to learn about critical matters in South Africa, such as the pervasive violence against foreign nationals. This visit yielded a renewed commitment from the South African government and churches to work jointly in fighting xenophobia in South Africa. In my view, this shows that the WCC works very hard to fight against the violation of the human rights of migrants. I thus contend, together with WCC (2009) that:

Beyond hospitality, however, the churches are a strong advocate and defender of the rights of people to move freely within their own nations and, when driven by poverty, insecurity and persecution, to leave their homes in search of their God given right to life with dignity. The church has recognized their responsibility to ensure that the public is properly informed on the root causes of migration and the factors that force people to leave their homes. We must confront racism, discrimination and xenophobia wherever and whenever it manifests itself; in churches, in our communities and our nations. (n.p.)

\section{Praying for struggling migrants, particularly refugees, in transit}

The WCC is conscious of the fact that some migrants, particularly refugees, use crude and dangerous modes of sea transport, which results in others perishing during the migration process (WCC 2015b). In 2015, some refugees from Africa drowned on the Mediterranean Sea whilst trying to cross to Europe (WCC 2015b). To substantiate the foregoing observation, Greene (2015:1) indicated that 2016 witnessed approximately 3800 Syrians, Afghans and Iraqis drowning in the Mediterranean Sea as they tried to escape from wars in their countries. Left with no choice, the desperate refugees try to sail to the other parts of the world using smugglers' 'rickety boats' that 'should never have sailed' (Greene 2015).

Hence, in reacting to the deaths of many African migrants on the Mediterranean Sea, the three General Secretaries of the WCC, the CCME and the CEC jointly issued a comprehensive letter advising their respective member churches and interrelated organisations to adopt sympathetic ecumenical responses to the challenges that refugees encounter before and upon arrival in Europe (Terfassa 2016:192; WCC 2015b). However, the three General Secretaries of the aforesaid intra-church Christian organisations did not only call for a sympathetic ecumenical response but prayed for the refugees who lost their lives on the Mediterranean sea and those who were still in transit. Prayers were also said for the Italian, Maltese and Greek coast guards who were largely left alone in the rescue efforts (Terfassa 2016; WCC 2015b). The General Secretaries also urged their member churches to pray for the refugees who face challenges in transit to their desired destinations. Whilst the WCC, the CCME and the CEC call for 'renewed solidarity and action and for a resumption and strengthening of a collective European response', they also prioritise prayer as an intervention, thus, acknowledging God's ability to change people's attitudes towards refugee and migrants crises across the globe (Terfassa 2016; WCC 2015b).

\section{Call to address the root causes of migration}

The WCC also responded to the migration crisis by calling on migrant sending countries to address the root causes of involuntary migration (WCC 2017a). Such causes include persecution, wars, political instabilities and natural disasters (i.e. famine and climate change) (Kantyka \& Kul 2015:123134; Terfassa 2016:191; WCC 2013b:n.p., 2017a:n.p.). Usually, involuntary migrants leave their countries of origin without proper documentation, as they do not have enough time to prepare for their migration (Kantyka \& Kul 2015; Terfassa 2016; WCC 2013b, 2017a). Thus, because of challenges beyond their control, some refugees are forced to migrate without acquiring the legal documents that are required in countries of desired destination, thus they are rendered stateless on arrival (Kantyka \& Kul 2015; Terfassa 2016; WCC 2013b, 2017a). Therefore, refugees are subject to different forms of exploitation and discrimination, such as being barred from accessing health and education services (Terfassa 2016:192). The WCC believes that migration inflows to economically and politically stable nations can be reduced by addressing the push factors (WCC 2016b:n.p.).

In the aforementioned comprehensive letter, the three General Secretaries also called on migrant sending countries to address the root causes of migration such as wars, persecution, inequalities, poverty, political instability, religious persecution and natural disasters, namely famine and climate change (WCC 2015b). This point was also reiterated at the WCC and United Nations (UN) conference on 20 January 2016 that called for coordinated efforts on refuge crises. Such efforts include promoting principled 'human rights-based and coordinated responses to refugees and migrants in Europe and to the root causes of their displacement' (WCC 2016b:n.p.). Indeed, this shows that the WCC responds appropriately to migration challenges.

\section{Provision of accommodation for migrants}

In Migration and Migrant Workers: Discerning Responses as Churches, the WCC notes the rapid increment in the number of migrants, especially women who become homeless in hosting countries (WCC 2011: n.p.). The document examines the migration situation of South East Asia, South Asia, the Middle East and Gulf Regions. It concludes that migrant workers largely fall victim to enormous emotional and psychological trauma because of being away from their families and the sub-human living conditions that they end up in (WCC 2011). Notably, 55\% of Asian migrant workers are women, most of whom are (WCC 2011):

$[A] \mathrm{re}$ often exposed to sexual abuse and harassment, harsh treatment and made to work long hours without any rest, healthcare and with little or no contact with anyone outside their work places. (n.p.)

These women and many other vulnerable migrants are usually in great need of support. In response, churches can run shelter homes for women in distress in order to mitigate the traumatic experiences through counselling and other relevant forms of support (WCC 2011). 
At its 10th Assembly in Busan, the WCC advanced its intervention to migration challenges, which focused on the provision of shelter to the vulnerable and homeless migrants (WCC 2013b:66). The 10th Assembly called on churches to provide accommodation for homeless refugees (WCC 2013b). It is critical to provide shelter for many homeless migrants because many of them struggle to find shelter upon their arrival in hosting countries (WCC 2013b). Churches should therefore uphold their God-given mission beyond ethnic and cultural boundaries by accommodating migrants from various national and ethnic backgrounds, as an expression of common witness in diversity and unity (WCC 2013b).

However, because of financial constraints, some churches may fail to offer shelter to homeless migrants, resulting in individual congregants resorting to accommodating the desperate migrants in their private homes (Goodall 2015:1718). Goodall (2015:17-18) also noted that a number of financially constrained churches resort to using their church buildings as sanctuaries for vulnerable migrants, some of whom are on the brink of being deported. By sheltering vulnerable illegal migrants who should be deported, some churches inadvertently break state laws. Consequently, some of these churches are raided by the police, who arrest and facilitate the deportation of all illegal migrants, in spite of the intervention of the churches (Goodall 2015).

\section{Conscientising societies and governments about the migration situation}

The WCC conscientises societies and governments about the migration situation. On 14 June 2016, the WCC convened a conference in Lunteren that called 'on churches and church-related organisations to significantly step up their participation in the public debate and in the advocacy efforts in the present refugee crisis' (WCC 2016a:2). The Lunteren Conference challenged churches and church-related organisations to raise awareness in their various societies about the exact nature of refugee crisis in Europe (WCC 2016a). In addition, the conference exhorted the Middle East countries such as Jordan and Lebanon, with the help of the UNHCR, to accept refugees from Syria, who were flocking to Europe (WCC 2016a). The Lunteren Conference also acknowledged the limitations of reception capacity within many European nations faced with the influx of Syrian refugees (WCC 2016a).

Whilst the WCC-led Lunteren Conference acknowledged the concerns of the European nations, it noted that the refuge crisis in Europe was also being manipulated for political purposes (WCC 2016a). The conference painted a vivid picture of the challenges faced by Syrian refugees, resulting in a call on all European nations, that were slow and unwilling to release the financial aid they had pledged, to financial support to states that were hosting many refugees in order to meet the refugees' basic needs (WCC 2016a). The conference also challenged the UNHCR and other humanitarian organisations to fulfil their role in addressing the Syrian refugee crisis, in transit and upon arrival in host nations
(WCC 2016a). Indeed, this shows how the WCC addresses migration challenges by conscientising government and relevant institutions or organisations with regard to the nature and extent of the migration situation so as to garner collective responses to the crisis.

\section{Strengths and weaknesses of the World Council of Churches' interventions to migration challenges}

The WCC's intervention of coordinating various stakeholders' responses to migration challenges is of utmost significance. This arises from the understanding that no governmental or non-governmental entity can deal with the complex issue of migration alone. Instead, various stakeholders work collaboratively to combat migration challenges (Terfassa 2016:189; World Economic Forum 2017:145). The Church, as a representative of God's kingdom in the world, that seeks to pursue justice and peace for the underprivileged (Jackson \& Passarelli 2016:28; WCC 2013b:2-4), should coordinate responses from various stakeholders to ensure that the rights of the vulnerable are protected and upheld. However, I am aware that one can argue that the role of assisting and protecting migrants primarily rests with the government. In responding to this conception, I argue that, from its biblical theological conviction, the Church should unswervingly uphold the dignity of all people, including migrants, because they are bearers of the image of God. That is to say, the Church should continue to exercise its God-ordained responsibility of caring for vulnerable migrants, even when the government fails to do so in times of crisis. This can be done by harnessing the efforts of all relevant players to ensure that comprehensive responses are realised. Regrettably, the WCC's role of coordinating migration responses is not well-stipulated in the council's fundamental documents ${ }^{5}$ that drive the member churches' responses to migrants' challenges. The WCC undertakes its coordination role on ad hoc basis, thus, there is no planned structure to ensure the realisation of comprehensive and collective stakeholder responses to migrants' challenges. Therefore, there is need for improved, intentional and well-planned coordination of stakeholders' responses and goodwill to migrants' challenges at national, local and municipal levels of the concerned countries and international institutions.

The WCC's intervention of providing material support such as food and sanctuary to vulnerable migrants is important because it aligns with what God sanctions his people to do for strangers in both the Old and New Testaments. For instance, in Deuteronomy 24:14-22, God commands the Israelites to share

5.The first document is titled $A$ moment to choose: Risking to be with uprooted people (WCC 1996:103-115). It challenges the international churches to address the issue of forcibly uproted people, which is a major crisis of our time. The church is issue of forcibly uprooted to take bold actions to become the church of the stranger by welcoming refugees, migrants and displaced people and standing with them. The second major document is titled The 'other' is my neighbour. Developing an ecumenical response to migration (WCC 2015a) and it constitutes analyses of biblical and theological aspects, as well as ecclesial implications and ecumenical responses to migration. None of these documents highlights the coordination of various stakeholders by the WCC. 
the fruits of the Promised Land of Canaan with landless aliens. The Israelites are commanded to practically care for vulnerable aliens and poor kinsmen by allowing them to glean in the harvested fields (Dt 24:19). This practice enables those without land to also benefit from the land of God (Brueggemann 2001:240). This means that the God of Israel is the God of all people, who cares for everyone, including the aliens, orphans and widows amongst the Israelites. Thus, I conclude together with Work (2009) that Deuteronomy 24:17-22:

Upholds justice for the least and provides for the destitute foreigners and orphans because he shows no favour (Deut. 10:17-22). The ones YHWH blesses with prosperity are his means of blessing sufferers, so that all who work in Israel are blessed. (p. 221)

This also applies in the New Testament. In Matthew 25:31-45, Jesus shows how God rewards those who look after the vulnerable such as migrants. Brown (2016:8) noted that Matthew 25:31-45 mentions 'the six moral characteristics' that 'are paradigmatic of Christian ethics' and not an extensive and definitive list of what Christ demands of his followers. Now, providing food for the hungry and sanctuary for the vulnerable is part of the six moral characteristics that serve as the ethical framework for believers. In commenting on Matthew 25:31-45, Morris (1992:638) and Arterbury (2007:21) agree that in both the Old and New Testament periods, acts of hospitality are hinged on welcoming strangers or travellers into one's home and offering them needful provisions and protection. Indeed, this is an expected and justified response to migrants' challenges. However, whilst these interventions are important, many churches, particularly in Africa, lack financial capacity to provide material support to vulnerable migrants (Magezi 2018:284, 289-291). That is to say, whilst the WCC calls on its member churches to provide material support to vulnerable migrants, it should acknowledge that many of its member churches do not have the financial resources to do so. Unfortunately, the WCC does not mention of its endeavour to raise money to support the migrant ministries of its member churches across the globe that are unable to meet material needs of migrants.

The WCC's call for its member churches to integrate migrants in the church through encouraging multicultural worship is a significant intervention. Nzayabino (2010), Kuzituka (2009) and Prill (2009:332) view multicultural worship as critical because culture and language are major barriers to the integration of migrants, particularly refugees, into local churches. Multicultural worship involves the holding of separate services for migrants and native people, as many member churches of the WCC are doing (Kuzituka 2009; Nzayabino 2010; Prill 2009). This approach is regarded as progressive (Kuzituka 2009; Nzayabino 2010; Prill 2009), although congregations seem to 'be divided by racial, national and tribal or linguistic identities' (Kwinyani 2018:15). In spite of the criticism, the approach is a pragmatic means of addressing language and culture barriers. To the adherents of the position that God, in and through Christ's redemptive work, inaugurated his ideal church that comprises people from all nationalities glorifying God together, the holding of separate services is not reflective of God's ideal church (cf. Barreto 2011:129; McGarry 2001:195; Williams 1997:24).

This notion is derived from Ephesians 2:11-22, where Paul argues that in and through Christ's redemptive work, God has created a new people from all nationalities (both Jews and Gentiles) that worship him together in unity, regardless of their distinct backgrounds (Magezi 2018:294). Thus, Paul's goal in Ephesians 2:11-22 is to perceive Jewish and Gentile Christians glorifying God together (Magezi 2018). Having said this, one can argue that the WCC member churches that have services and bible studies in migrants' vernacular to address the problem of language for migrant worshippers are deviating from the notion of the one body of Christ that Ephesians 2:11-22 reinforces (Magezi 2018). However, Magezi (2018:295) argued that it is naïve to criticise churches for holding separate services in response to migrants' language problems. Magezi argued that although the above-mentioned reasons can be used as the basis to criticise the practice of conducting worship in the vernacular languages of the migrants, in Ephesians 2:11-22, Paul does not mention that the Christians are facing a language problem (Magezi 2018). Instead, because of their ethnic and religious background differences, the Jewish and Gentile Christians think that they are better than one another (Magezi 2018).

Given the fact that language barriers hamper migrant worshippers' understanding of the preachers' messages, the WCC member churches' responses to such a challenge should be applauded (Magezi 2018:294). This is important because Christians from different linguistic and cultural backgrounds can be edified and experience spiritual growth when services are conducted in their mother tongues (Magezi 2018). God desires both spiritual and numerical growth of the church, which migrant worshippers can only experience when they understand the language in which services are conducted (Magezi 2018). Some churches' failure to address the language problem results in the emergence of many migrant churches, as migrants desire to continue with familiar church traditions, as well as create a home away from home feel (Magezi 2018).

However, although multicultural worship is a commendable way of addressing language barriers, this approach deprives the migrants an opportunity to learn the native languages and up-skill themselves in other ways (Bryers, Winstanley \& Cooke 2014:9-18; Omidvar 2016:n.p.; Ros I Sole 2014:55-78). Learning native languages and other skills is critical because it assists the migrants to be easily integrated in the employment sectors and native societies (Bryers, Winstanley \& Cooke 2014; Omidvar 2016; Ros I Sole 2014). Mallows (ed. 2014) noted that:

Basic knowledge of the host society's language, history and institutions is indispensable to integration; enabling immigrants to acquire this basic knowledge is essential to successful integration. (p. 2) 
Likewise, in a research titled What drives the language proficiency of immigrants? Immigrants differ in their language proficiency along a range of characteristics, Isphording (2015:1) argued that 'language proficiency is a key driver of immigrant integrations. It increases job opportunities and facilitates social and political participation'. The immigrants that fail to achieve adequate proficiency in the host country's language generally fail to achieve economic and social integration (Isphording 2015). In the context of this discussion, it does not matter whose responsibility it is to teach the migrants the languages of the host countries. Instead, as Terfassa (2016) noted:

[What matters are that the] challenges we face in relation to ... integration are too big to be solved by a single church or society. They call for a change of attitude by every one of us. We need to avoid prejudices which have built walls of separation and to recognise one another as members of the same family. (p. 189)

Thus, in heeding to Terfassa's (2016) call, I argue that churches can take it upon themselves to teach the migrants the languages of host countries so that they can be integrated in all sectors of host countries. However, it is regrettable that the current integration of the migrants within the member churches of the WCC seems to be narrowly focused, as it tends to only emphasise separate worship services. However, given that many churches have limited financial resources to address the complex material needs of migrants (Kwinyani 2018:14-17; Magezi 2018:289-291), one can argue that starting language classes for migrants would suffice as a productive approach that would relieve the churches of the burden of care, as the migrants that would have up-skilled could start working and earning enough to sustain themselves. This is a complex and costly approach; however, it gives leverage and opportunity for churches to utilise their limited resources to take care of newly arrived migrants.

The WCC's intervention of conscientising societies, governments (national level) and international institutions about the situation of migration helps all the relevant stakeholders to be aware of the emerging migration issues and challenges. Consequently, this assists all stakeholders and partners to adopt relevant responses to migration challenges. The conscientisation role is crucial, as the WCC can relay any information on emerging migration challenges to other stakeholders so that they make collective efforts to combat such challenges. Unfortunately, the WCC is not currently using multiple platforms, such as social media and exhibitions, which could ensure a wider reach of the awareness intervention (Terfassa 2016:202). The WCC's intervention of calling various governments and relevant nations to address the root causes of migration is expected and justified, as supported by a considerable number of scholars such as Carling and Tallerra (2016:1-40) and Mckeon (2018:1-16) who call for all stakeholders to address the root causes of migration. These scholars propound an unusual angle that underscores that as long as the aforementioned root causes of migration exist, many countries will continue to face an influx of migrants, particularly refugees. In view of the rampant Syrian refugee crisis in Europe, the United Nations, which is the guardian and leading international advocate for human rights, urged national governments to adopt humane resettlement programmes and address the primary causes of migration (Grandi 2016:n.p.).

The WCC's intervention of praying for migrants who are experiencing challenges in transit and upon arrival in host countries is crucial because it brings them (migrants) before the throne of God, who protects them and provides for their needs in miraculous ways (Magezi 2018:301-302). Magezi (2018) stated that prayer depicts the following three things about the church: (1) it depends on God to address the challenges of migrants; (2) it acknowledges God as the primary defender of the vulnerable migrants; and (3) it acknowledges that it works hand in hand with God, under the grace and power of the Spirit of God who indwells Christians and, consequently, the church (Magezi 2018:338). That is (Magezi 2018):

The Church has to always pray for God to provide resources for the church to be able to minister to migrants' physical and spiritual needs effectively. As God's agent appointed to look after the vulnerable on earth, the church should unceasingly pray for God to guide it and use it faithfully as it undertakes its mandate of caring for the vulnerable, such as migrants. It has to continue to ask God to protect and safeguard migrants from the physical, emotional and spiritual harm that they experience in the various spheres of life. (p. 338)

Finally, the WCC's intervention of advocating for the human rights of migrants is of enormous significance in the contemporary context of migration, whereby many countries are now prohibiting more migration inflows (Mckeon 2018:1-16). For instance, amidst the current global challenge of the Covid-19 pandemic, the USA President, Donald Trump signed an executive order to stop the issuing of Green Cards for 60 days ostensibly to protect Americans from competing for jobs with foreigners (Kapur 2020). Furthermore, in reviewing the situation of the Syrian refugees who are flocking to Europe, Plucinka (2015) noted that some European countries wilfully violate the rights of some displaced people. In order to discourage the stranded migrants from entering their countries, these European countries resorted to tightening their borders and imposing onerous visa regulations (Plucinka 2015).

The above-mentioned anti-migration measures violate the recommendation of the United Nations Human Rights Office of the High Commissioner (UNHRC 2013:16). The UNHRC upholds the Universal Declaration of Human Rights of 1948 that allows people to move from their countries of origin if their government does not protect and fulfil their social, political and economic rights. The declaration also stipulates that the receiving nations are obligated to protect migrants. Furthermore, the declaration upholds that all states have an obligation 'to respect, protect and fulfil the human rights of all migrants' (UNHRC 2013:16). It follows that the nations that are signatories to the international human rights and customary laws of migration are not permitted to return 'anyone to a country where they would be at risk of persecution, torture or other serious human social violations' (UNHRC 2013:16). Upon their arrival in hosting nations, 
migrants, especially those without legal documentation, suffer several forms of discrimination and violation of their rights to health, education, accommodation and employment (Magezi 2018:278-281). Thus, by advocating for migrants to get legal documents, the WCC helps them to access some basic services that require them to have some form of legal documentation (Magezi 2018).

\section{Recommendations to strengthen the World Council of Churches' interventions to migration challenges}

From the aforementioned discussion, the following recommendations for improving the WCC's response to migration challenges can be discerned:

- The WCC should have a planned coordination role in order to effectively harness efforts of various stakeholders' responses to migration challenges. This would enable the organisation to realise comprehensive responses to migrants' challenges.

- The WCC should raise some funds to help financially constrained churches to address the migrants' material and legal documentation needs.

- The WCC should assist migrants to integrate in the employment sectors and native societies by equipping them with job skills, including the native languages of the host nations.

- There is need to encourage collective effort from all nations and various stakeholders to address the push factors of migration in order to reduce the number of people embarking on international migration and, consequently, putting a strain on the host countries' resources.

- I agree with Terfassa (2016:202) that the WCC should also use exhibitions and multimedia (TV programmes, websites and concerts and music festivals) to raise awareness of the migration situation, instead of only utilising ad hoc meetings, publications and conferences. In order to raise cultural awareness and understanding of the plight of migrants, the WCC can use diversity workshops, courses of study and individuals who can share their stories and experiences of dislocation (Terfassa 2016).

\section{Conclusion}

This article reviewed the WCC's responses to migration challenges in order to gain insight into the broader approaches employed by churches. The article established that WCC member churches utilise integrated approaches to migration issues. However, some of the churches do not adequately execute some of the interventions because of limited finances and others, in the course of assisting migrants, tend to break national laws. Succinctly put, the WCC has remarkable migration intervention strategies. However, some of these interventions have inherent weaknesses, which can be countered by adopting the abovestated recommendations.

\section{Acknowledgements Competing interests}

The author has declared that no competing interest exists.

\section{Author's contributions}

C.M. is the sole author of this research article.

\section{Ethical consideration}

This article followed all ethical standards for research without direct contact with human or animal subjects.

\section{Funding information}

This research received no specific grant from any funding agency in the public, commercial or not-for-profit sectors.

\section{Data availability statement}

Data sharing is not applicable to this article as no new data were created or analysed in this study.

\section{Disclaimer}

The views and opinions expressed in this article are those of the authors and do not necessarily reflect the official policy or position of any affiliated agency of the authors

\section{References}

Adele, H., 2012, 'Migration and multicultural ministries as mission', International Review of Mission 101(2), 408-414. https://doi.org/10.1111/j.1758-6631. 2012.00119.x

African Press Office (APO), 2019, 'World Council of Churches (WCC) delegation meets with South African President Ramaphosa to discuss gender-based violence and violence on foreign nationals in South Africa', CNBCAFRICA, viewed 23 April 2020, from https://www.oikoumene.org/news/wcc-delegation-meets-with-south-africanpresident-ramaphosa.

Arterbury, A., 2007, Entertaining angels: Hospitality in Luke and Acts, Center for Christian Ethics at Baylor University, Waco, TX.

Barreto, E.D., 2011, 'Negotiating difference: Theology and ethnicity in the Acts of the Apostles', Word \& World 31(2), 129-137.

Bose, S., 2014, 'Illegal migration in the Indian Sunderbans', Forced Migration Review 45, viewed 30 April 2020, from https://www.fmreview.org/sites/fmr/files/ FMRdownloads/en/crisis/bose.pdf.

Bread for the World, 2016, World church leader offers Ten Commandments of Food viewed 27 April 2020, from https://www.bread.org/blog/world-church-leaderoffers-ten-commandments-food.

Brown, T., 2016, Exegesis of Matthew 25:31-36 with an emphasis on the identity of all the nations and the least of these, viewed 31 March 2020, from https://www. academia.edu/34353125/Exegesis of Matthew_25_31_46_with_an_Emphasis on_the_Identity_of_All_the_Nations_and_the_Least_of_These_.

Brueggemann, W., 2001, Deuteronomy: Abingdon Old Testament Commentaries, Abingdon Press, Nashville, TN.

Brunn, S.D., 2001, 'World Council of Churches as a global actor: Ecumenical space as geographical space', Geographica Slovenica 34(1), 65-78.

Bryers, D., Winstanley, B. \& Cooke, M., 2014, 'Whose integration?', in D. Mallows (ed.), Language issues in migration and integration: Perspectives from teachers learners, pp. 9-18, British Council, London.

Carling, J. \& Tallerra, C., 2016, Root causes and drivers of migration Implications for humanitarian efforts and development cooperation, viewed 30 April 2020, from https://www.researchgate.net/publication/283118771_Migration_mission_and the_multi-ethnic_church.

Castles, S. \& Wise, R.D., 2008, Migration and development: Perspectives from the South, International Organisation for migration, viewed 04 May 2020, from https://publications.iom.int/books/migration-and-developmentperspectives-south.

Chelius, L.C., 2014, Mexicans seeking political asylum, viewed 28 April 2020, from https://www.fmreview.org/sites/fmr/files/FMRdownloads/en/crisis/ calderon.pdf. 
Cloud, D.W., 2013, The World Council of Churches, Way of Life, Port Huron.

Corhen, J.H. \& Sirkerci, I., 2011, Cultures of migration: The global nature of contemporary mobility, University of Texas Press, Austin, TX.

Gilmore, K., 2016, Keynote address: Side event migrants in transit by Deputy High Commissioner for human rights, viewed 20 May 2016, from https://www.ohch org/EN/NewsEvents/Pages/DisplayNews.aspx?NewsID=18485\&LangID=E

Goodall, C., 2015, Shouting towards the sky: The role of religious individuals, communities, organisations and institutions in support for refugees and asylum seekers, viewed 27 April 2020, from https://www.unhcr.org.

Grandi, P., 2016, Solutions needed to stem global refugee crisis, says new UN agency, viewed 30 April 2020, from https://news.un.org/en/story/2016/01/519502 solutions-needed-stem-global-refugee-crisis-says-new-un-agency-chief.

Greene, R.A., 2015, 'Migrant crisis: 2016 is the deadliest year for Mediterranean', CNN News, viewed 23 April 2020, from https://edition.cnn.com/2016/10/26/europe/ mediterranean-migrant-crisis-visual-guide-trnd/index.html.

Isphording, I.E., 2015, What drives the language proficiency of immigrants? Immigrants differ in their language proficiency along a range of characteristics, viewed 06 May 2020, from https://wol.iza.org/articles/what-drives-languageviewed 06 May 2020, from http
proficiency-of-immigrants/long.

Jackson, D. \& Passarelli, A., 2016, Mapping migration, mapping churches' responses in Europe, viewed 23 May 2016, from http://www.ccme.be/../2016-01-08Europe, viewed 23 May 2016, from http://w
Mapping_Migration_2015_Online_lo-res_2_.pdf.

Kantyka, P. \& Kul, W.T., 2015, 'World Council of Churches towards migration and poverty', Studia Oecumenica 15, 123-134.

Kapur, S., 2020, Trump halts immigration for 60 days: Here's what the president's order means, viewed 28 April 2020, from https://www.nbcnews.com/politics/ white-house/trump-s-immigration-ban-raises-more-questions-answers-heres-n1188946.

Kuzituka, D.J.M., 2009, 'National identity and immigration from Africa: Relationships between Black South Africans and African Immigrants in Yeoville, Johannesburg', Master's thesis University of the Witwatersrand, Johannesburg.

Kwinyani, K., 2018, Monocultural churches in an age of migration, viewed 28 April 2020, from https://www.biblesociety.org.uk/content/explore the bible/bible in_transmission/files/2018_spring/Monocultural_churches_in_an_age_of migration.pdf.

Magezi, C., 2017, 'Migration crisis and the church: A response to lacunae and considerations for Christian ministry engagement', Verbum et Ecclesia 38(1), a1671. https://doi.org/10.4102/ve.v38i1.1671

Magezi, C., 2018, 'Theological understandings of migration and church ministry model: A quest for holistic ministry to migrants in South Africa', PhD thesis, NorthWest University, Potchefstroom.

Mallows, D. (ed.), 2014, Language issues in migration and integration: Perspectives from teachers learners, British Council, London.

Mckeon, N., 2018, Getting to the root causes of migration' in West Africa - Whose history, framing and agency counts?, viewed 30 April 2020, from https://
migrationresearch.com/item/getting-to-the-root-causes-of-migration-in-westmigrationresearch.com/item/getting-to-the-root-causes-of
africa-whose-history-framing-and-agency-counts/542274.

McGarry, C., 2001, 'A community of disciples to witness to the kingdom', in C. McGarry \& P. Ryan (eds.), Inculturating the church in Africa: Theological and practical perspectives, pp. 195-196, Pauline Publications, Nairobi.

Morris, L., 1992, The gospel according to Matthew, William B. Eerdmans, Grand Rapids, MI.

Nzayabino, V., 2010, 'The role of refugee-established churches in integrating forced migrants: A case study of Word of Life Assembly in Yeoville, Johannesburg', HTS Teologiese Studies/Theological Studies 66(1), Art. \#290, 9 pp. https://doi. org/10.4102/hts.v66i1.290

Omidvar, R., 2016, 'The biggest issues facing migrants today and what we can do to solve them', World Economic Forum, viewed 30 April 2020, from https://www. weforum.org/agenda/2016/11/the-biggest-issues-facing-migrants-today/.

Oxley, S.M., 2010, 'The World Council of Churches and "ecumenical consciousness": How the constitutional responsibility of fostering "ecumenical consciousness" has been reflected in the World Council of Churches' educational and formational activities from 1948-2006', PhD thesis in Humanities, University of Manchester, Manchester.

Plucinska, J., 2015, The Paris attack have put Europe's refugee crisis under renewed scrutiny, viewed 27 May 2016, from https://time.com/4114009/paris-attacksmigrant-crisis-refugees-eu/.

Press Release No: 15/35, Refugee crisis: Ecumenical organisations respond, World Council of Churches, viewed 22 September 2020, from https://www.ceceurope. $\mathrm{org} /$ refugee-crisis-ecumenical-organisations-respond/.

Prill, T., 2009, Migration, mission and the multi-ethnic church, in D Parker (ed.), Evangelical Review of Theology 33(4), 332-346.

Van der Bent, A.J., 1986, Christian response in a world of crisis: A history of the WCC's commission of the churches on international affairs, World Council of Churches, Geneva.

Van Eideren, M., 1990, Introducing the World Council of Churches, World Council of Churches, Geneva.
Raiser, K., 1997, To be the church: Challenges and hopes for the new millennium, World Council of Churches, Geneva.

Rajendra, T.M., 2014, 'Justice and benevolence: Catholic social thought, migration theory, and the rights of migrants', Political Theology 15(4), 290-306. https://doi. org/10.1179/1462317X13Z.0000000007

Ridsdel, J., 2014, 'Adolescence, food crisis and migration', Forced Migration Review 45, 27-28.

Ros I Sole, C., 2014, 'The paradoxes of language learning and integration in the European context', in $\mathrm{D}$. Mallows (ed.), Language issues in migration and integration: Perspectives from teachers learners, pp. 55-78, British Council, London.

Stromberg, J., 2003, 'Responding to the challenge of migration: Churches within the fellowship of the World Council of Churches (WCC)', Missiology: An International Review XXXI(1), 44-50. https://doi.org/10.1177/009182960303100107

Terfassa, D.O., 2016, 'Migration and inclusive community', in D. Field \& J. Koslowski (eds.), Prospects and challenges for the ecumenical movement in the 21st century: Insights from the Global Ecumenical Theological Institute, pp. 189-205, Globeethics.net Library, Geneva.

Thomsen, P.M., 2016, The refugee surge in Europe: Economic challenges, viewed 28 May 2016, from https://www.imf.org/external/pubs/ft/sdn/2016/sdn1602.pdf.

Tulun, M.O., 2020, 'What is the World Council of Churches? Centre for Eurasian Studies (AVIM)', Commentary 2014(34), 1-4, viewed 13 April 2020, from https:// avim.org.tr/en/Yorum/WHAT-IS-THE-WORLD-COUNCIL-OF-CHURCHES.

United Nations Human rights office of the High Commissioner (UNHRC), 2013, Migration and human rights: Improving Human Rights-Based Governance of international migration, viewed 30 April 2020, from https://www.ohchr.org/ Documents/Issues/Migration/MigrationHR_improvingHR_Report.pdf.

WCC, 1996, A moment to choose: Risking to be with uprooted people, WCC Publications, Geneva, viewed 28 April 2020, from https://onlinelibrary.wiley.com/ doi/abs/10.1111/j.1758-6631.1996.tb02736.x.

WCC, 2009, Message of the World Council of Churches, viewed 23 April 2020, from http://www.vatican.va/roman_curia/pontifical_councils/migrants/ pom2009_111-suppl/rc_pc_migrants_pom111-suppl_welcome-marchetto.html.

WCC, 2011, Migration and migrant workers: Discerning responses as churches, viewed 23 April 2020, from https://www.oikoumene.org/resources/documents/ migration-and-migrant-workers-discerning-responses-as-churches.

WCC, 2013a, WCC 10th Assembly, Busan, 2013, World Council of churches, Geneva, viewed 13 April 2020, from http://wcc2013.info/en.html.

WCC, 2013b, 'Advocacy for the rights of stateless people', World Council of Churches, viewed 22 April 2020, from https://www.oikoumene.org/news/ churches-advocate-for-the-rights-of-stateless-people-0.

WCC, 2015a, "The "other" is my neighbour. Developing an ecumenical response to migration', WCC Publications, Geneva, viewed 22 April 2020, from https://www. oikoumene.org/resources/publications/the-other-is-my-neighbour.

WCC, 2015b, A worldwide fellowship of churches seeking unity, a common witness and Christian service, viewed 03 March 2020, from www.oikoumene.orgipresscentresnewsichurches-mourn-loss-of-.

WCC, 2016a, 'Lunteren Ecumenical Conference 14-16 June 2016', WCC Lunteren, viewed 21 April 2020, from https://www.scribd.com/ document/357068452/3-pdf.

WCC, 2016b, 'UN conference calls for coordinated action on refugee crisis, WCC, viewed 23 April 2020, from https://www.oikoumene.org/news/wcc/unconference-calls-for-coordinated-action-on-refugee-crisis.

WCC, 2017a, 'Churches' advocacy for the rights of stateless people in Europe', World Council of Churches, viewed 22 April 2020, from https://www.statelessness.eu/ updates/blog/churches-advocacy-rights-stateless-people-europe.

WCC, 2017b, Statement from World Council of Churches on the U.S. immigration ban, viewed 28 April 2020, from https://www.eurodiaconia.org/2017/02/ statement-from-world-council-of-churches-on-the-u-s-immigration-ban/.

WCC, 2018a, World Conference on xenophobia, racism, and populist nationalism in the context of global migration, viewed 21 April 2020, from https://www. oikoumene.org/events/world-conference-on-xenophobia-racism-and-populistnationalism-in-the-context-of-global-migration.

WCC, 2018b, How can you help refugees?, viewed 27 April 2020, from https://www. oikoumene.org/news/how-can-you-help-refugees.

Williams, D.R., 1997, 'The right thing to do: A divided church and what to do about it', Adventist Review 174, 24-26.

Work, T., 2009, Deuteronomy: Brazos Theological commentary on the Bible, Brazos Press, Grand Rapids, MI.

World Economic Forum, 2017, Migration and its impact on cities, viewed 28 April 2020, from http://www3.weforum.org/docs/Migration_Impact_Cities_report_2017_ low.pdf.

World Migration Report, 2020, Migration World Report 2020, viewed 04 May 2020, from International Migration, Health and Human Rights, https://publications.iom. int/system/files/pdf/wmr_2020.pdf.

Yoo-Crowe, S. \& Crowe, C. (eds.), 2000, Multicultural ministry: Report of the First International Network Forum, Uniting Church in Australia, Sydney. 